\title{
The Effect of Good Corporate Governance on Stickiness Cost Level of Manufacturing Companies Listed on Indonesia Stock Exchange in Period of 2017-2018
}

\author{
Kresna Murty*, Nurafni Eltivia, Atika Syuliswati \\ Accounting Department \\ State Polytechnic of Malang \\ Malang, Indonesia \\ *womurty@gmail.com, nurafni.eltivia@polinema.ac.id, atikasyuliswati@gmail.com
}

\begin{abstract}
The purpose of this research is to find out whether SG\&A cost is sticky and to see whether good corporate governance is able to reduce the level of stickiness cost. Population of this research were manufacturing companies listed on Indonesia stock exchange in the period of 2017-2018. Sample was chosen using purposive sampling technique with total sample of 111 companies. Analysis model used in this research was multiple regression which processed using SPSS 25 assistance. This research found that SG\&A cost increased by 0.275 percent when sales increased by $1 \%$. While SG\&A cost decreased by $0.068 \%$ when sales decreased by $1 \%$. The result of this research also found that gcg is able to reduce the level of stickiness cost.
\end{abstract}

Keywords-component, stickiness cost, good corporate governance, anti-sticky, $S G \& A$ cost

\section{INTRODUCTION}

The progress of accounting literature in recent years has much focused on cost behavior which changes are not balanced with changes in the volume of activity. Cost accounting literature describes two basic types of cost behavior, namely fixed costs and variable costs. Generally, it is assumed that fixed costs are constantly unchanged and are not affected by the rate of change in activity volume. While the amount of variable costs is proportionally changed by the rate of change in activity volume. However, there is assumption that cost behavior where changes in costs occurs disproportionately to changes in activity volume [1].

The disproportionate cost change is a cost behavior where the amount of cost change depends on changes in activity. Cost changes, when the activity both increases and decreases are disproportionately caused by an imbalance in the response of costs to activity changes. This imbalance in the cost response to changes in activity is known as stickiness cost behavior. A cost is said to be sticky when the increase in costs is greater than the decrease in changes in activity by an equivalent amount [2].
Cost is not proportionally changed with activity changes due to the imbalance resources adjustment so that stickiness cost happens. The main cost of stickiness cost is Uncertainty about the future demand for products sold by the company which results in managers tend to choose to keep unused resources rather than reduce resources when sales decline. However, if manager chooses to adjust the costs, stickiness cost will not be happened [3].

Traditional theory stated that changes in costs run symmetrically with changes in net sales. Recent studies have shown that costs respond asymmetrically to increases and decreases in net sales [3]. Cost behavior is called sticky or anty-sticky costs when the cost response to decreasing activity is smaller or greater than when the firm's activity increases. Stickiness cost behavior is also related to managers' decisions in dealing with demand uncertainty in the future [4].

Stickiness cost behavior associated with managers' decisions can arise when managers make decisions and adjust volume. resources to the demand for fluctuating output. Fluctuating demand causes a number of unused resources, such as unemployed employees [3]. These unused resources will still create high costs even though there is a decrease in activity and will cause stickiness cost behavior. This stickiness cost behavior can have a bad impact on the company where the higher the level of stickiness cost behavior in the company, the more difficult the company will be to achieve profit [5]

Apart from the use of resource management, the calculation of production cost cannot be separated from the problem of cost, because the cost of goods is a collection of direct labor, factory overhead and direct material costs, all of which need to be considered the level of use in a product in order to create an effective cost of goods manufactured. Production costs can be considered effective and efficient if the resulting production has a standard quantity and quality that is proportional to the appropriate price, so that the costs incurred can be said to be 
efficient and do not contain any indication of waste, then management needs to evaluate various factors of production costs so that efficiency is created and reduce standard costs which of course affect the company's profitability [6].

In improving their performance, managers must have a lot of experience in making decisions within the company. The thing that is no less important in the business of a manufacturing company called a going concern is that managers must understand how the company is in managing its business in its operational activities. Going concern is a condition where the company as a business entity can operate in the future which is influenced by financial and non-financial conditions and will not be liquidated in the short term. In carrying out its operational activities, the company is inseparable from the problem of costs, both production costs and non-production costs that are incurred so that these products are sold for sale.

Contributions to stakeholders such as agents, customers, society and government are also expected to be the main focus of Good Corporate Governance (GCG), not only focusing on the internal parties of the company (management and employees). In addition, GCG will also encourage the formation of a management work pattern that is transparent, clean, and professional.

In Indonesia, GCG implementation becomes an important and widely discussed issue. The seriousness of the Indonesian government in implementing GCG in Indonesia was proven in 1999 by the Indonesian government to form a committee called the National Committee on Corporate Governance and in 2004 it was changed to the National Committee for Governance Policy which consisted of the Public Sub-Committee and SubCommittee. The National Committee on Corporate Governance issues GCG guidelines that are issued to companies in Indonesia including companies operating on the basis of sharia principles, and these GCG guidelines contain the basic principles and basic guidelines for implementing GCG. The purpose of establishing these committees and guidelines is to promote a healthy business climate and become part of the efforts to uphold the principles of GCG in Indonesia (KNKG, 2006). In GCG, there are several elements, such as share ownership structure, frequency of audit committee meetings, audit quality, and independent commissioners.

\section{THEORETICAL REVIEW}

\section{A. Stickiness Cost}

Asymmetric cost behavior or stickiness cost was first introduced by Malcom [7] who found that some costs tend not to be easy to adjust because of high fixed costs. Asymmetric cost behavior arises when there is an asymmetric behavior in making resource adjustments, which tends to slow down the process of decline compared to the process of increasing the use of resources. The manager's role in tailoring resources when responding to change activities related to change requests. Managers can recognize and control stickiness cost behavior by considering the sensitivity of changing costs [8].

Research on stickiness costs uses sales, administration and general (SG\&A) costs as a measure in determining the stickiness cost behavior that appears in the company. SG\&A used several considerations: 1) stickiness costs are found more in SG\&A costs than in other operating expense categories [8], 2) SG\&A costs are widely considered and calculated by analysts and investors and 3) SG\&A costs have a strong relationship with changes in income, where many components of SG\&A costs are influenced by the level of company income [8].

The empirical research data on SG\&A costs behaves asymmetry, that is, when demand increases, costs increase and when demand decreases, costs do not experience a significant decrease [8]. Previous studies of stickiness cost were divided into 2 points of view. The first perspective of research is focused on the impact of economic factors on the level of stickiness costs. Economic law makes it clear that managers have the right to make decisions when there is a decrease in demand to cut or maintain SG\&A costs [8].

\section{B. Good Corporate Governance}

In order to add value to the company in the long term sustainably, good corporate governance describes a structured process for shareholders while still taking into account the interests of other stakeholders, based on applicable laws [9].

According to Sukandar and Rahardja [10] The concept of implementation and good corporate governance focuses on the rights of stakeholders to obtain accurate, correct and timely data. Every company (especially public companies), applies good corporate governance rules. According to FCGI (Forum for Corporate Governance Indonesia) [11], stated that Good Corporate Governance is a regulatory instrument that regulates the relationship between internal and external stakeholders related to their rights and obligations, or in other words a system that focuses on corporate control efforts. To create added value for the company and all stakeholders need the concept of corporate governance.

The concept of Corporate Governance which is carried out through a system of supervision and monitoring of company management performance aims to improve the performance of a company and reveal to stakeholders that the company's accountability is based on applicable regulations. To achieve the management of the company's financial statements more transparent for all stakeholders put forward the concept of GCG, in addition to helping with the GCG also create an environment contribution to the creation of efficient and sustainable growth in the corporate sector.

\section{Agency Theory}

Agency theory describes the relationship between agent (manager) and principal (owner), this theory is used as a reference to explain corporate governance [12]. In practice, the owner will give authority to the manager expecting that the manager will give his best to achieve the goals of the owner, namely maximizing company value. However, problems arise from the separation of ownership and management, which is known as agency problems. Conflicts between stakeholders (agents and principals) are called agency problems 
According to Soemarso [13] The main theory that underlies the management of a company is known as Agency Theory. This theory is especially true when there is a separation between the owners (shareholders) and the management of the company. Owner is the principal. Meanwhile, management is an agent (agent). Shareholders delegate their duties and authority to management to manage their company

To reduce problems or conflicts that occur between owners and management, a supervisory mechanism is needed for company management. The mechanism that can be used is GCG. GCG is expected to be a system that provides guidelines and principles to harmonize the different interests of managers and shareholders [14].

\section{HYPOTHESIS}

\section{A. The Existence of Stickiness Cost in Manufacturing Companies}

This research used net sales as the proxy of sales volume, while the cost proxy used SG\&A cost variable. The significant impact of business operating cost is SG\&A cost [15]. Variation in marketing, administrative and general costs, when net sales increase is greater than when net sales decline. This means marketing, administrative and general costs are sticky [16]. From the above statement, hypothesis 2 is as follows:

$\mathrm{H}_{1}=\mathrm{SG} \& \mathrm{~A}$ costs in manufacturing companies listed on IDX in 2017-2018 are sticky.

\section{B. Good Corporate Governance in Reducing Stickiness Cost}

Corporate governance refers to a set of mechanisms to monitor or motivate managers when ownership and control are separated. Some of the mechanisms are market operations controlled by the board of directors, institutional and corporate shareholders [17]. When managers make decisions in the best business interests, their goals can be achieved more effectively thanks to good corporate governance. If not. The role of supervision is increasingly important, because good corporate governance can reduce management opportunities while protecting the interests of actors. From the above statement, hypothesis 2 is as follows:

$\mathrm{H}_{2}=$ Good Corporate Governance could reduce the Stickiness level of SG\&A cost of manufacturing companies listed on IDX in 2017-2018.

\section{RESEARCH METHODS}

The objects used in this research are manufacturing companies listed on the Indonesia Stock Exchange in 20162018. Based on the sampling criteria and by using purposive sampling, there are 111 manufacturing companies that meet the requirements for completeness and data needs in this research. Type of research used was quantitative, the research to be carried out is included in quantitative research. Quantitative research is an objective research approach that includes the collection and analysis of quantitative data and uses statistical testing methods [18].

The population and research sample were taken based on purposive sampling technique, namely the sampling method was not random and only met certain criteria or conditions that could be used as a research sample.

Dependent variable used in this research was SG\&A cost as a proxy for stickiness cost. The dependent variable in this study is stickiness cost, the dependent variable itself is the variable that is affected because of the independent variable (free). As in Anderson's research [8]. This study compares the SG\&A costs for a certain period (t) with the SG\&A costs for the previous period $(\mathrm{t}-1)$ using the following formula:

$$
\left[\frac{S G \& A_{i, t}}{S G \& A_{i, t-1}}\right]
$$

Meanwhile, the independent variables used in this study are net sales, net sales dummy and discretionary accruals. The independent variable is a variable that has a major influence on other variables or affected variables. This variable has a fixed value or the amount is not determined by other variables [19]. The following is an explanation of each independent variable:

\section{A. Net sales}

Net sales are used as a proxy for sales volume. The value of a certain period's net sales (t) will be compared with the previous period's net sales period (t-1) using the following formula [20]:

$$
\text { Net sales }=\left\lceil\frac{N S_{i, t}}{N S_{i t-1}}\right\rceil
$$

\section{B. Net sales dummy}

The net sales dummy is a variable that multiplies the dummy value and the comparison of net sales in period $t$ with net sales in period $\mathrm{t}-1$. The following is the formula for these variables [20]:

$$
\text { Net sales dummy }=\text { Dummy }_{i, t} *\left\lceil\frac{N S_{i, t}}{N S_{i, t-1}}\right\rceil
$$

If company $\mathrm{i}$ experiences an increase in net sales, then the net sales dummy will be worth 0 , if company $i$ experiences a decrease in net sales it will be worth 1 .

\section{Good Corporate Governance}

Ownership of the number of shares in a company by nonfinancial and financial entities, whether domestic or foreign, is called institutional ownership. Institutional ownership is measured based on the percentage of institutional share ownership [21]:

$$
\text { Dummy }_{\mathrm{i}_{2} t} *\left[\frac{\mathrm{NS}_{\mathrm{i}, \mathrm{t}}}{\mathrm{NS}_{\mathrm{i}_{\mathrm{i}} \mathrm{t}-\mathrm{1}}}\right] *\left[\frac{\text { Institutional share ownership }}{\text { Total shares outstanding }}\right]
$$

The analytical tool in this study uses multiple linear regression because it has more than one variable. The analysis procedure begins with a classical assumption test, then tests the 
first and second hypotheses. There are two regression equation models in this study. To test the existence of stickiness cost, this study uses the regression equation model owned by Anderson et al. [20]. Here is the regression equation model:

$$
\begin{gathered}
\log \left[\frac{S G \& A_{i, t}}{S G \& A_{i, t}-1}\right]=\beta_{0}+\beta_{1} \log \left[\frac{N S_{i, t}}{N S_{i, t-1}}\right] \\
+\beta_{2} D_{\text {ummy }} * \log \left[\frac{N S_{i, t}}{N S_{i, t-1}}\right]+\varepsilon_{i, t}
\end{gathered}
$$

The dummy value is 0 when there is an increase in sales, conversely when there is a decrease in sales the dummy value will be 1 . Since the dummy value is 0 when net sales increase, the coefficient $\beta_{1}$ shows the percentage increase in SG\&A costs every $1 \%$ increase in net sales. Meanwhile, the dummy value will change to 1 when net sales have decreased, so that the sum of the coefficients $\beta_{1}$ and $\beta_{2}$ shows the percentage of cost reduction every $1 \%$ decrease in net sales. If the SG\&A costs are sticky, then the percentage increase must be greater than the percentage decrease. Thus, the basis for $\mathrm{H}_{1}$ is:

$$
\beta_{1}>0 ; \beta_{2}<0
$$

Furthermore, to test the ability of earning management to reduce the level of stickiness costs, the equation model used is that of Farzaneh et al. [22]. The following is the regression equation model:

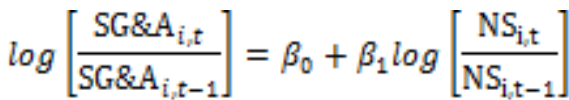

$$
\begin{aligned}
& +\beta_{2} \text { Dummy } * \log \left[\frac{\mathrm{NS}_{\mathrm{it}}}{\mathrm{NS}_{\mathrm{i}, \mathrm{t}-1}}\right]+ \\
& \beta_{\mathrm{a}} \text { Dummy } * \log \left[\frac{\mathrm{NS}}{\mathrm{NS} S_{\mathrm{i} t-1}}\right] * \mathrm{KI}+\varepsilon_{\mathrm{i}, t}
\end{aligned}
$$

Just like the previous equation, if net sales have increased, the dummy value will be 0 , while the dummy value will be 1 if the situation is the opposite. Since the dummy value is 0 when net sales increase, the coefficient $\beta_{1}$ shows the percentage increase in SG\&A costs every $1 \%$ increase in net sales. Meanwhile, the dummy value will change to 1 when net sales have decreased, so that the sum of the coefficients $\beta_{1}, \beta_{2}$ and $\beta_{3}$ shows the percentage of cost reduction every $1 \%$ decrease in net sales which is influenced by the variable good corporate governance (proxied by institutional ownership). If good corporate governance can reduce the level of stickiness cost at SG\&A costs, then the coefficient $\beta_{2}$ must be negative and $\beta \_3$ must be positive. Thus, $\mathrm{H} \_2$ is:

$$
\beta_{1} \text { and } \beta_{3}>0 ; \beta_{2}<0
$$

$$
\beta 1 \text { and } \beta 3>0 ; \beta 2<0
$$

\section{RESULTS AND ANALYSIS}

To determine the existence of stickiness costs in manufacturing companies in Indonesia, as well as to determine whether good corporate governance can reduce the level of stickiness costs, first, this study conducted a descriptive statistical analysis of the first and second hypothesis. Descriptive statistical analysis provides an overview of the maximum value, minimum value, average value (mean) and standard deviation of the variables studied. Second, performing a classic assumption test consisting of normality, multicollinearity, heteroscedasticity and autocorrelation tests before testing first and second hypothesis, this is done to determine whether the data is suitable for analysis or not, because not all data can be re-analyzed. Furthermore, this study uses the regression equation model from Anderson [8] to test the first hypothesis. The results of the first hypothesis testing describe as follows:

TABLE I. HyPOTHESIS TEST RESULTS 1

\begin{tabular}{|l|l|l|}
\hline \multirow{2}{*}{ Model } & \multicolumn{2}{c|}{$\begin{array}{c}\text { Unstandardized } \\
\text { Coefficients }\end{array}$} \\
\cline { 2 - 3 } & \multicolumn{1}{|c|}{ B } & \multicolumn{1}{c|}{ Std. Error } \\
\hline (Constant) & 0,014 & 0,006 \\
\hline Net sales & 0,275 & 0,084 \\
\hline Dummy net sales & $-0,207$ & 0,239 \\
\hline
\end{tabular}

Based on Table 1, it can be seen that the coefficient value $\beta 1>0$ is 0.275 and the coefficient value $\beta 2<0$ is equal to 0.207. In addition, through this table it can be seen the percentage of increase and decrease in SG\&A costs. Every $1 \%$ increase in net sales will increase SG\&A costs by 0.207 , whereas every $1 \%$ decrease in net sales will decrease SG\&A costs by $(0.275-0.207) 0.068 \%$. Thus, it can be concluded that the first hypothesis is accepted because the percentage increase is greater than the percentage decrease. in other words, SG\&A costs in manufacturing companies listed on the IDX in 2017 2018 are sticky. This research is in line with research conducted by Susilo [16] which states that the variation in marketing, administration and general (SG\&A) costs when net sales increase is greater than when net sales have decreased. This means marketing, administrative and general costs are sticky.

TABLE II. HYPOTHESIS TEST RESULTS 2

\begin{tabular}{|l|l|l|}
\hline \multirow{2}{*}{ Model } & \multicolumn{2}{c|}{$\begin{array}{c}\text { Unstandardized } \\
\text { Coefficients }\end{array}$} \\
\cline { 2 - 3 } & \multicolumn{1}{|c|}{ B } & Std. Error \\
\hline (Constant) & 0,015 & 0,006 \\
\hline Net Sales & 0,337 & 0,091 \\
\hline Net sales Dummy & $-1,616$ & 0,460 \\
\hline GCG & 3,382 & 0,889 \\
\hline
\end{tabular}

Source: Data processed by SPSS

Based on table 2, it can be concluded that institutional share ownership can reduce the level of stickiness cost, because the coefficient $\beta_{1}>0$ is 0.337 , the coefficient value $\beta_{2}<0$ is -1.616 , and the coefficient value $\beta_{3}>0$ is 3.382 . Meanwhile, every $1 \%$ increase in net sales will increase PAU costs by $0.337 \%$ and the presence of institutional stock ownership will reduce PAU costs by $2.103 \%$ for every $1 \%$ decrease in net sales. Thus, it 
can be concluded that the second hypothesis is accepted because/ institutional share ownership is able to reduce the level of stickiness costs. This study is in line with Melinda [23] which states that the better corporate governance, the higher the CSR disclosure. After determining CSR activities, managers will not find it easy to reduce investment in CSR activities, causing cost stickiness. The proxies used to measure good corporate governance consist of 3 proxies, namely independent commissioners, board of directors and institutional ownership.

\section{CONCLUSION AND SUGGESTION}

From the research results it can be concluded that there is an indication of sticky cost behavior in SG\&A costs. SG\&A costs when sales are up, the increase is greater than the decrease in SG\&A costs when sales are down. This is because the largest component of SG\&A costs is fixed costs, whose changes are constantly not influenced by changes in activity volume. In addition, the tendency of managers to maintain unemployed resources when sales decline also causes stickiness cost behavior.

Furthermore, the research result shows that good corporate governance can increase the stickiness cost of SG\&A. This can occur because institutions, both government and institutions, monitor every activity in financing in order to get maximum profit.

Based on the research results, several suggestions can be made for further research. This study has limitations, namely the proxies used to measure Good Corporate Governance only use one of the proxies, namely institutional ownership. It is expected that further research can increase the number of independent variables such as: independent commissioners, board of directors, audit committee and managerial ownership.

\section{REFERENCES}

[1] S.R. Vonna, "Analisis Perilaku Sticky Cost Pada Biaya Produksi dan Non-Produksi (Studi Empiris Pada Perusahaan Manufaktur Yang Terdaftar di Bursa Efek Indonesia Periode 2011-2014)" Jurnal Ilmiah Mahasiswa Ekonomi Akuntansi (Jimeka), vol. 1, no. 1, pp. 120-132, 2016.

[2] L. Ratnawati, "Perilaku Sticky Cost Biaya Penjualan, Biaya Administrasi dan Umum Serta Harga Pokok Penjualan Pada Perusahaan Manufaktur," Jurnal Ekonomi Dan Bisnis, vol. XVIII, no. 2, 2015.

[3] M. Anderson, "Cost Behavior And Fundamental Analysis Of Sg\&A Costs," Journal Of Accounting, Auditing \& Finance, 2004.

[4] J. Abu-Serdaneh, "The Asymmetrical Behavior Of Cost: Evidence From Jordan," International Business Research, vol. 7, no. 8, 2014.
[5] D. Weiss and I. Kama, "Do Managers' Deliberate Decisions Induse Sticky Costs?" Henry Crown Institute Of Business Research; Working Paper No 16/2011, 2011.

[6] L. Hidayat, "Analisis Biaya Produksi Dalam Meningkatkan Profitabilitas Perusahaan,” Jurnal Ilmiah Manajemen Kesatuan, vol. 1, no. 2, 2013

[7] R.E. Malcom, "Overhead control implications of activity costing," Accounting Horizons, vol. 5, no. 4, p. 69, 1991.

[8] M. Anderson, "Are Selling, General, And Administrative Cost "Sticky"?" Journal Of Accounting Research, vol. 41, no. 1, 2003

[9] Komite Nasional Kebijakan Corporate Governance, Pedoman Good Corporate Governance Perbankan Indonesia, 2004

[10] P. Sukandar and Rahardja, "Pengaruh Ukuran Dewan Direksi dan Dewan Komisaris Serta Ukuran Perusahaan Terhadap Kinerja Keuangan Perusahaan," Diponegoro Journal Of Accounting, vol. 3, no. 3, pp. 1-7, 2014.

[11] Forum for Corporate Governance in Indonesia, Corporate Governance: Tantangan dan Kesempatan bagi Komunitas Bisnis Indonesia. Jakarta: Prentice Hall, 2001.

[12] Mutmainah and Wijayanti, "Pengaruh Penerapan Corporate Governance Terhadap Kinerja Keuangan Pada Perusahaan Perbankan Yang Terdaftar Di Bursa Efek Indonesia," Diponegoro Journal Of Accounting, vol. 1, no. 2, 2012

[13] S.R. Soemarso, Pengantar Akuntansi, Edisi keempat. Rineka Cipta Jakarta, 2008

[14] H. El-Chaarani, "The Impact of Corporate Governance on the Performance of Lebanese Banks," The International Journal of Business and Finance Research, vol. 8, no. 5, pp. 22-34, 2014.

[15] E. Chen, "Are Family Firms More Tax Agresive Than Non-Family Firm?” Journal Of Financial Economics, pp. 41-61, 2010.

[16] E. Susilo, “Analisis Perilaku Sticky Cost Dan Pengaruhnya Terhadap Prediksi Laba Menggunakan Model Cost Variability Dan Cos Stickiness (CVCS) Pasda Emiten di BEI Untuk Industri Manufaktur,' Akademi Akuntansi Keuangan Dan Perbankan Indonesia, vol. 2, no. 2, 2016 .

[17] D.F. Larcker, "Corporate Governance, Accounting Outcomes, And Organizational Performance," The Accounting Review, vol. 82, no. 4, pp. 963-1008, 2007

[18] A. Hermawan, Penelitian bisnis. Jakarta: PT. Grasindo, 2009.

[19] D. Wisadirana, Metode penelitian \& pedoman penulisan skripsi untuk ilmu social. Malang : UMM Press, 2005.

[20] M. Anderson, R.D. Banker, and S.N. Janakiraman, "Are Selling, General, and Administrative Cost "Sticky"?" Journal of Accounting Research, vol. 41, 2003

[21] G. Novalia, "Pengaruh Good Corporate Gocernance Terhadap Nilai Perusahaan Dengan Return On Assets Sebagai Variabel Moderating Pada Perusahaan Manufaktur Yang Terdaftar Di Bursa Efek Indonesia Tahun 2011-2014," Jurnal Jurusan Akuntansi, Fakultas Ekonomi Universitas Maritim Raja Ali Haji Tanjungpinang, 2016.

[22] N. Farzaneh, S.M. Javad, S. Mahdi, and B.S.A. Haddad. "A Study of The Stickiness of Cost of Goods Sold and Operating Cost to Changes in Sales Level in Iran," Studies in Business and Economic, vol. 8, no. 2, 2013.

[23] V. Melinda, "Pengaruh Good Corporate Governance Terhadap Cost Stickiness Dengan Earning Management dan Corporate Social Responsibility Sebagai Mediasi Pada Perusahaan Manufaktur Yang Terdaftar di BEI Tahun 2014-2016,” Repositoru Unair, 2016. 